

\section{The Impact of Organizational Learning Capability on Product Innovation Performance: Evidence from the Turkish Manufacturing Sector}

\section{Özlem Yaşar Uğurlu Mustafa Kurt}

\section{Introduction}

Recent studies argue that organizational learning is a must for businesses (Garcia-Morales et al. 2007) and that it represents a modern approach to management that could solve many problems which businesses encounter (Aydemir, 2000, Santos-Vijande and Alvarez-Gonzalez, 2007). Organizational learning capability, a closely related concept, has not received the same level of attention given to organizational learning. In the literature on management, organizational learning capability is defined as an organizational capability that makes effective organizational learning possible by managing the process of organizational learning (Gomez et al., 2005). Innovation is another concept that has received a lot of attention in recent years. Many studies describe innovation as a critical factor for organizational survival in the contemporary world. Studies on innovation usually employ a comprehensive definition that includes innovation in processes, services, structure, and management (Hult et al., 2004). Product innovation is another type of innovation that allows a more precise measurement. There are many studies establishing the strong positive relationship between innovation and organizational learning (Hurley and Hult, 1998;
Damanpour, 1991; Goes and Park, 1997), but the number of studies examining the relationship between innovation and organizational learning capability is very limited (Alegra and Chiva, 2008). Focusing on organizational learning capability rather than on organizational learning would contribute to the literature by helping fill this important gap. In addition, most of the existing studies were conducted in Anglo-Saxon countries, with a dearth of studies on developing economies. Within this framework, the present study aims to examine the relationship between organizational learning capability and product innovation performance of manufacturing firms in Turkey, and identify the dimensions of organizational learning capability that affect product innovation performance.

\section{Literature Review}

\subsection{Organizational Learning Capability}

Organizational learning and organizational learning capability are treated separately in the relevant literature, with the former being defined as an effort to develop methods for the generation and practical management of organizational knowledge (Calantone et al., 2002). According to another definition, provided by Argyris, organizational learning takes place when members of an organization identify and correct mistakes in the prevailing behavioral theory of the organization and respond to changes in the internal and external environment, and the new knowledge is recorded in the organizational memory (Sinkula et al., 1997). Organizational learning capability, on the other hand, consists of the features that shape the process of organizational learning. Organizational learning 
capability refers to the ability of an organization to engage in management activities in line with structures and procedures that support and facilitate learning (Goh, 2003). According to another definition, organizational learning capability refers to patterns of action that allow an organization to process knowledge and experience, generate new knowledge on the basis of existing knowledge and experience, and store knowledge for later use when the need arises (Garbi, 1998; Ussahawanichakit, 2008). Hsu and Fang (2008) define organizational learning capability as the ability to adopt and transfer new knowledge, and to use this knowledge in the process of product development for competitive advantage and higher production speeds. In yet another attempt, Pinar and Arıkan (2015) define organizational learning capability as the ability of an organization to develop new knowledge and approaches that could potentially affect the existing mode of operation of the organization. Finally, March (1991) examines organizational learning capability from two different perspectives: exploitation and exploration. The first approach, exploitation, views organizational learning as the accumulation of knowledge and experience. In this approach, the main organizational capabilities are failure detection and correction (Argyris and Schön, 1996) and memory and organizational routines (Walsh and Ungson, 1991; Nonaka and Takeuchi, 1995; Prahalad and Hamel, 1994; Prieto and Revilla, 2006). The second approach, exploration, emphasizes the exploratory nature of organizational learning capability. In this approach, organizational learning is seen as the driving force behind change, flexibility, and innovation (Prieto and Revilla, 2006). According to this approach, the main organizational capabilities are scanning, problem solving
(Simon, 2000), variety of ideas (Van de Ven and Polley, 1992), and organizational renewal (Senge, 2007; Barr et al., 1992).

The first organizational learning capability is the ability of an organization to detect failures and correct them for future action plans. The absence of this capability results in repeated failure and faulty learning (Fiol and Lyles, 1985; Garbi, 1998). Garvin argues that organizations need to conduct systematic reviews their successes and failures to be able to learn (Lynn et al., 2000).

Operation and implementation routines are related to organizational routines such as rules, policies, and standard operating procedures concerning knowledge, communication, and coordination systems. Organizational routines (regular and predictable behaviors implicit in processes and product and service standards) are important avenues for learning to take place (Spicer and Smith, 2006). For organizational learning to take place, there must be proper mechanisms in place to transfer the acquired knowledge from the individual employee to the team, and from the team to the larger organization (Jerez et al. 2008). In addition, operation and implementation routines serve as knowledge stores developed by organizations to respond to structural or frequent problems (Garbi, 1998; Weick, 1991). They show that the organization has the ability to store, transfer, and remember past experiences, in other words, organizational memory (Huber, 1991; Walsh and Ungson, 1991). Organizational learning is closely related to past experiences stored in the memory. These records and experiences greatly facilitate employees' access to knowledge (Lynn et al., 2000). 
Problem solving is another organizational learning capability. In addition to rules and procedures to deal with frequently repeated structural problems, organizations must have problem solving skills to overcome new problems for which no previous action plan exists (Garbi, 1998). The problem solving capability of an organization is also a reflection of its ability to generate new knowledge (Cohen and Levinthal, 1990). Problem solving skills allow organizations to interpret new knowledge, and question and re-define existing knowledge (Singh, 2006).

Scanning refers to the ability of an organization to collect information on its external environment and identify threats and opportunities (Daft and Weick, 1984). Scanning capability is necessary for the generation of new and appropriate knowledge. Environmental scanning involves conducting research on customers, competitors, suppliers, and technological trends and regulatory changes affecting the sector. This knowledge is usually acquired through informal means such as individual contacts and social networks, not through formal channels (Hambrick, 1982). This is done to ensure that the efforts of employees are based on valid knowledge of the internal and external environment of the organization (Singh, 2006).

This dimension refers to the ability of an organization to create many new ideas and approach issues from different perspectives. This ability distributes new solutions, new perspectives, and new knowledge throughout the organization (Singh, 2006). It is related to the structural characteristics of the organization (Garbi, 1998), and involves searching for new solutions to problems using novel methods and procedures (Alegre and Chiva, 2008).

Continuous renewal, the last item on the list of organizational learning capabilities, refers to the ability of an organization to continuously search for new ways of overcoming obstacles to organizational change and new methods of doing business more effectively (McGill and Slocum, 199; Senge, 2007). This capability is implicit in Huber's (1991) definition of organizational learning as a change in the organization's field of potential behaviors, and Argyris' definition of organizational learning as removing obstacles to organizational change. This dimension of organizational learning capability has been studied in the context of elements that facilitate organizational change, such as flexibility, inclusiveness, creativity, and teamwork (Koffman and Senge, 1993; McGill and Slocum, 1993; Senge, 2007).

\subsection{Innovation and Product Innovation}

Innovation, the focus of much recent topic in the literature, has been defined in different ways. According to Garcia and Calantone (2002), innovation refers to change that result in commercial benefit and that is based on new ideas or implementation of existing knowledge in novel ways. Atik (2005) defines innovation as "the process of transforming an idea into a marketable product or service, or into a new or improved method of manufacturing or distribution". The U.S. National Science Foundation defines innovation as the transformation of knowledge into products, processes, systems, or services (Atik, 2005). According to another definition provided by Amabile et al. (1996), innovation is the successful implementation of creative ideas in an 
organization. Thompson defines innovation as the production, adoption, and implementation of new ideas, processes, products, and services (Yeung et al., 2007; Oskarsson, 2003). Finally, Schumpeter defines innovation as the use of inventions to create new commercial products or services. According to Schumpeter, innovation is a driving force behind the creation of demand for goods and services (Kirchhoff, 1994). In addition to the definitions of the concept of innovation, there are also a number of classifications in the literature. The two most commonly used classifications are based on the degree (radical or gradual) and focus (product or process) of innovation (Güleş and Bülbül, 2004). Atik (2005) classifies innovation into three types: product innovation, process innovation, and organizational innovations. In another classification, Özen and Bingöl (2007) offer a fourfold typology: product innovation, process innovation, marketing innovation, and organizational innovation. Hult et al. (2004) argue that a new service or product, a new manufacturing process, a new structure or administrative system can all be described as innovation. Durna (2002), on the other hand, classifies innovation into categories of product and process innovation, radical and incremental innovation, and business innovation.

Apart from these definitions and classifications regarding innovation in general, product innovation is defined in the literature as a change in the products manufactured or services offered by a firm. Batmaz and Özcan (2008) define product innovation as the transformation of an idea into a marketable, new/improved product, method, or service at the end of the production process. According to another definition, product innovation refers to a new product/service or an improvement that increases the life cycle or competitiveness of an existing product or service; it means the launch of a new product or service or major improvements in the functional or user features of existing goods and services (Durna, 2002; Özen and Bingöl, 2007). There are two types of product innovation: new products and improved products. A new product is a product that significantly differs from previous ones with its technological features. The novelty of the new product may be the result of new knowledge, a novel combination of existing technologies, or a radical new technology. An improved product, on the other hand, is the result of an improvement in the performance of an existing product (Batmaz and Özcan, 2008).

Product innovation performance, one of the focuses of the present study, is a multi-dimensional concept. Researchers use different performance assessment criteria depending on the focus of their studies. For example, Hsu and Fang (2008) examined product development performance in terms of market performance, financial performance, customer performance, and product performance. According to Freeman, product innovation is a process that includes technical design, research and development, production, and administrative and commercial activities for the marketing of a new or improved product (Alegre and Chiva, 2006). The present study measures product innovation performance in two dimensions: innovation efficacy and innovation efficiency. Both dimensions are widely discussed in the literature on innovation. Innovation efficacy measures the market performance of an innovation, using indicators such as product range, market share, and expansion to new markets, and captures the level of success of an innovation. Innovation 
efficiency, on the other hand, measures the amount of effort spent for an innovation project to succeed (Alegre and Chiva, 2008). This study measures innovation performance using a metric that combines both aspects.

\section{The Relationship between Organizational}

\section{Learning Capability and Product Innovation}

\section{Performance}

As mentioned above, organizational learning capability involves the generation and use of new knowledge that improves organizational performance. Learning is key for speed and flexibility in the process of product development, and systematic learning on the basis of past experiences is critical in the first stages of product development process (Nederhof et al., 2002). An organization that is capable of generating new knowledge and integrating it with existing knowledge using different methods is expected to perform well in terms of product innovation and manufacturing process. In addition, the process of developing new products requires continuous organizational renewal (Calantone et al., 2002). In this context, learning capability is seen as a key factor for an organization to innovate (Jerez, 2005; Alegre and Chiva, 2008; Sinkula et al. 1997; Calantone et al. 2002). A learning-focused company would have the knowledge and skills to understand and meet customer needs, to better analyze rivals' strengths and weaknesses, and to be more effective in drawing lessons from failures and successes. Such companies would also be more effective in making innovation compared to their competitors, and make more innovations (Garcia- Morales et al. 2007). There are other studies in the literature examining the relationship between organizational learning capability

The Impact of Organizational Learning Capability on Product Innovation Performance: Evidence from the Turkish Manufacturing Sector and product innovation performance. Lynn et al. (1999), for example, found that higher levels of organizational learning were associated with higher levels of success in product development. In other words, an increase in organizational learning capability is accompanied by a parallel increase in innovation capability (Hsu and Fang, 2008; Ussahawanitchakit, 2008; Akgün et al. 2007; Phromket and Ussahawanicthakit, 2009). Innovation is a process of individual and collective learning that facilitates finding new methods to solve problems, and is associated with learning capability, which makes it possible for an organization to generate, transfer and make use of new knowledge (Alegre and Chiva, 2008; Sinkula et al. 1997; Calantone et al. 2002). Therefore, we hypothesize the following:

Hypothesis 1: Dimensions of organizational learning capability have a positive effect on product innovation efficiency (effort spent on successful innovation).

Hypothesis 2: Dimensions of organizational learning capability have a positive effect on product innovation efficacy (level of success of an innovation). 


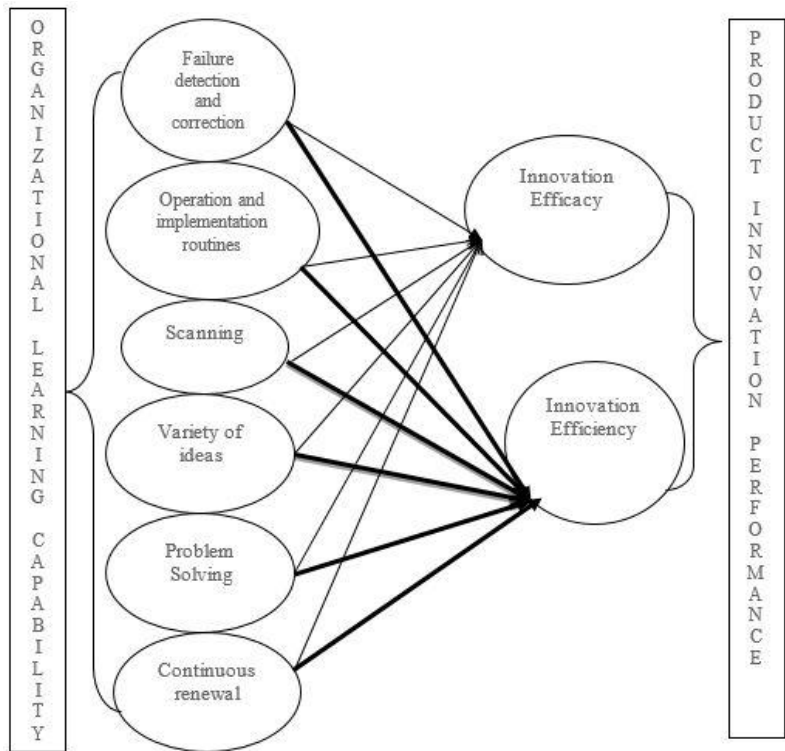

Figure 1. Conceptual Model of the Research

Source: Figure complied by authors

\section{Research Methodology}

This study aims to examine the effects of organizational learning capability on the dimensions of product innovation performance. To this end, a survey was conducted with 407 firms that were among the largest 1000 firms of Turkey according to Istanbul Chamber of Commerce's 2008 data, and that had their head offices in Istanbul. Istanbul was chosen because it is the province with the largest manufacturing capacity in Turkey, making the largest contribution to overall economy, and is the city from which the greatest numbers of patent applications originate according to the Turkish Patent Institute. A decision was made to conduct a survey with high level executives of 120 manufacturing companies, representing $30 \%$ of the population, who were selected using stratified random sampling from each sector. Appointments were made with high level executives (general manager, assistant general manager, R\&D manager, etc.) of the 120 firms selected using stratified random sampling. The survey was conducted using face to face interviews with the executives whenever possible, and via e-mail or phone when that option was not available. The following table reports the total number of firms by sector and the number of firms that participated in the study, and provides a description of the 31 NACE codes used to identify sectors.

Table 1: The Number and Distribution of Firms to Sectors using the 31-item NACE List

\begin{tabular}{|c|c|c|c|}
\hline $\begin{array}{l}\text { NACE } \\
\text { CODE }\end{array}$ & NACE Description & $\begin{array}{c}\text { Number } \\
\text { of Firms } \\
\text { in the } \\
\text { Sector }\end{array}$ & $\begin{array}{c}\text { Number of } \\
\text { Firms } \\
\text { Participating } \\
\text { in the Study, } \\
30 \% \text { of the } \\
\text { Total, Selected } \\
\text { Using } \\
\text { Stratified } \\
\text { Sampling }\end{array}$ \\
\hline DA & $\begin{array}{l}\text { Manufacture of food } \\
\text { products, beverages, } \\
\text { and tobacco }\end{array}$ & 49 & 14 \\
\hline DB & $\begin{array}{l}\text { Manufacture of } \\
\text { textiles and textile } \\
\text { products }\end{array}$ & 72 & 21 \\
\hline DC & $\begin{array}{l}\text { Manufacture of } \\
\text { leather and leather } \\
\text { products }\end{array}$ & - & - \\
\hline $\mathrm{DD}$ & $\begin{array}{l}\text { Manufacture of wood } \\
\text { and wood products }\end{array}$ & 5 & 1 \\
\hline $\mathrm{DE}$ & $\begin{array}{l}\text { Manufacture of pulp, } \\
\text { paper, and paper } \\
\text { products; publishing } \\
\text { and printing }\end{array}$ & 22 & 7 \\
\hline DF & $\begin{array}{l}\text { Manufacture of coke, } \\
\text { refined petroleum } \\
\text { products, and nuclear } \\
\text { fuel }\end{array}$ & 11 & 3 \\
\hline DG & $\begin{array}{l}\text { Manufacture of } \\
\text { chemicals, chemical } \\
\text { products and man- } \\
\text { made fibers }\end{array}$ & 44 & 13 \\
\hline DH & $\begin{array}{l}\text { Manufacture of } \\
\text { rubber and plastic } \\
\text { products }\end{array}$ & 22 & 7 \\
\hline DI & $\begin{array}{l}\text { Manufacture of other } \\
\text { non-metallic mineral } \\
\text { products }\end{array}$ & 33 & 10 \\
\hline DJ & $\begin{array}{l}\text { Manufacture of basic } \\
\text { metals and fabricated } \\
\text { metal products }\end{array}$ & 69 & 21 \\
\hline DK & $\begin{array}{l}\text { Manufacture of } \\
\text { machinery and } \\
\text { equipment n.e.c. }\end{array}$ & 48 & 14 \\
\hline DL & $\begin{array}{l}\text { Manufacture of } \\
\text { electrical and optical } \\
\text { equipment }\end{array}$ & 10 & 3 \\
\hline $\mathrm{DM}$ & $\begin{array}{l}\text { Manufacture of } \\
\text { transport equipment }\end{array}$ & 20 & 6 \\
\hline $\mathrm{DN}$ & Manufacturing n.e.c. & - & - \\
\hline & TOTAL & 405 & 120 \\
\hline
\end{tabular}

Source: Table complied by authors 
The questionnaire consisted of 53 items, eight of which were multiple choice questions, and 43 Likert scale items. Of the 43 five-point Likert scale items in the questionnaire, 32 measured dimensions of organizational learning capability, and 11 measured product innovation performance. The questionnaire was developed using scales that are shown to have high validity and reliability in the literature. To measure dimensions of organizational learning capability, the scale used in Garbi’s (1998) doctoral dissertation titled "Contingencies of Learning: Essays on the Strategic Implications of Organizational Learning, Organizational Environments and Knowledge Sharing" was implement, along with the scale used by Yeung et al. (1999). Six dimensions of organizational learning capability were examined: Failure detection and correction, operation and implementation routines (organizational memory), scanning, variety of ideas, continuous renewal, and problem solving. The reliability figure for the dimensions of organizational learning capability varied between 0.721 and 0.817. KMO (Kaiser-Meyer-Olkin Measure of Sampling Adequacy) sampling adequacy coefficient, which is a measure of appropriateness of exploratory factor analysis, was 0.749 . The results of Bartlett's Test of Sphericity, conducted to determine whether meaningful factors could be extracted, were satisfactory $(665,579 ; \mathrm{p}<0.000)$. The six factors extracted explain $62.806 \%$ of the total variance.

The scale used to measure product innovation performance, on the other hand, consisted of two dimensions: product efficacy, which measures the level of success of an innovation, and product efficiency, which measures the effort spent on successful innovation.
To measure product innovation, the scale used by Alegre and Chiva (2008) in their article titled, "Assessing the Impact of Organizational Learning Capability on Product Innovation Performance: An Empirical Test" was implemented. Product efficacy dimension consists of items that measure market performance of products, such as the expansion of product range, market share, and expansion into new markets. Performance criteria for product efficiency, on the other hand, underlined the importance of the efficiency of the product development process, and focused on the speed and total cost of product development. This scale has been used in a number of previous studies (Valle and Avella, 2003; Alegre et al. 2006). The reliability coefficient of the scale is 0.743 for the efficiency dimension, and 0.751 for the efficacy dimension. KMO (Kaiser-Meyer-Olkin Measure of Sampling Adequacy) sampling adequacy measure was 0.833. The results of Bartlett's Test of Sphericity were satisfactory $(336,278 ; \mathrm{p}<0.000)$. The two factors extracted explain $60.669 \%$ of the total variance.

\section{Analysis of Findings}

In terms of the demographics of participants, most executives who participated in the study were heads of human resources or $\mathrm{R} \& \mathrm{D}$, followed by general managers and board members. A great majority of the participants had 5 to 15 years of management experience. Most firms who participated in the study were active in their sector for at least 15 years, and had more than 250 employees. Almost all of the firms who participated in the study had a formal R\&D department, and more than half cooperated with a technology development institute such as TEKMER (Technology Development Center), 
TÜBİTAK (The Scientific and Technological Research

Council of Turkey), or Teknokent (Technocity). As a result, the number of utility model patents developed by the firms that participated in the study was relatively high. The contribution of new products, developed within the last five years, to total sales, was around $50-60 \%$ for most of the participants. A great majority of the firms that participated in the study have export levels of about $50 \%$, and many have no foreign partners.

Table 2: Research and Development Activities of the Firms

\begin{tabular}{|c|c|c|}
\hline $\begin{array}{l}\text { Has partnership with a technology development } \\
\text { institute }\end{array}$ & $\mathbf{N}$ & $\%$ \\
\hline Yes & 69 & 57.5 \\
\hline No & 51 & 42.5 \\
\hline $\begin{array}{l}\text { The number of utility model patents registered } \\
\text { within the last five years }\end{array}$ & $\mathbf{N}$ & $\%$ \\
\hline Less than 5 & 10 & 8.3 \\
\hline $5-10$ & 17 & 14.2 \\
\hline $11-15$ & 6 & 5.0 \\
\hline $15-20$ & 69 & 57.5 \\
\hline More than 20 & 18 & 15.0 \\
\hline Formal R\&D Department & $\mathbf{N}$ & $\%$ \\
\hline Yes & 103 & 85.8 \\
\hline No & 17 & 14.2 \\
\hline $\begin{array}{l}\text { Share of new products developed within the last } \\
\text { five years in total sales }\end{array}$ & $\mathbf{N}$ & $\%$ \\
\hline Less than $10 \%$ & 8 & 6.7 \\
\hline $15-20 \%$ & 9 & 7.5 \\
\hline $25-35 \%$ & 7 & 7.5 \\
\hline $40-50 \%$ & 6 & 5.0 \\
\hline $50-60 \%$ & 60 & 50.0 \\
\hline More than $60 \%$ & 30 & 25.0 \\
\hline Share of Exports & $\mathbf{N}$ & $\%$ \\
\hline Less than $5 \%$ & 7 & 5.8 \\
\hline $5-10 \%$ & 11 & 9.2 \\
\hline $11-20 \%$ & 3 & 2.5 \\
\hline $21-35 \%$ & 9 & 7.5 \\
\hline $36-49 \%$ & 67 & 55.8 \\
\hline More than $50 \%$ & 23 & 19.2 \\
\hline Foreign Partner & $\mathbf{N}$ & $\%$ \\
\hline Yes & 26 & 21.7 \\
\hline No & 94 & 78.3 \\
\hline
\end{tabular}

Table 3: Correlations between Organizational Learning Capability and Dimensions of Product Innovation Performance

\begin{tabular}{|c|c|c|c|c|c|c|c|c|c|c|}
\hline Variables & Mean & S. & 1 & 2 & 3 & 4 & 5 & 6 & 7 & 8 \\
\hline $\begin{array}{l}\text { 1. Operation } \\
\text { and } \\
\text { Implementatio } \\
\text { nRoutines } \\
\text { 2. Problem }\end{array}$ & 4.09 & 0.49 & $(0.721)$ & & & & & & & \\
\hline $\begin{array}{l}\text { Solving } \\
\text { 3. Scanning }\end{array}$ & $\begin{array}{l}3.85 \\
4.10\end{array}$ & $\begin{array}{l}0.44 \\
0.38\end{array}$ & $\begin{array}{l}0.262^{*} \\
0.449^{*}\end{array}$ & $\begin{array}{l}(0.745) \\
0.508^{*}\end{array}$ & $(0.761)$ & & & & & \\
\hline $\begin{array}{l}\text { 4. Continuous } \\
\text { Renewval } \\
5 \text {. Variety }\end{array}$ & 4.03 & 0.50 & $0.404^{* *}$ & $0.421^{* *}$ & $0.498^{* *}$ & $(0.801)$ & & & & \\
\hline $\begin{array}{l}\text { of Ideas } \\
\text { 6. Failure } \\
\text { Detection and }\end{array}$ & 3.9 & 0.44 & $0.437^{* *}$ & $0.481^{*}$ & $0.411^{* *}$ & $0.345^{\circ *}$ & $(0.752)$ & & & \\
\hline $\begin{array}{l}\text { Detectuon and } \\
\text { Correction }\end{array}$ & 4.00 & 0.40 & $0.536^{*}$ & $0.408^{* \prime}$ & $0.509^{* *}$ & $0.398^{* *}$ & $0.475^{*}$ & $(0.817)$ & & \\
\hline $\begin{array}{l}\text { 7. Innovation } \\
\text { Efficacy }\end{array}$ & 3.97 & 0.481 & $0.554^{*}$ & $0.476^{*}$ & $0.552^{* *}$ & $0.360^{\circ}$ & $0.454^{*}$ & $0.703^{*}$ & $(0.751)$ & \\
\hline $\begin{array}{l}\text { 8. Innovation } \\
\text { Efficiency }\end{array}$ & 4.02 & 0.479 & $0.490^{* *}$ & $0.351^{* *}$ & $0.523^{* *}$ & $0.388^{* *}$ & $0.344^{* *}$ & $0.632^{* *}$ & $0.729^{* *}$ & $(0.743)$ \\
\hline
\end{tabular}

${ }^{* *}$ Significant at 0.01 level (two-way)

Table 3 shows that there is a strong relationship between innovation efficiency and innovation efficacy. In other words, when the effort spent on successful innovation increases, so does the level of success of the innovation. Failure detection and correction, which is an important dimension of organizational learning capability, has a very strong and positive relationship with both innovation efficacy; that is to say, the level of success of an innovation, and innovation efficiency. Operation and implementation routines are also highly positively correlated with the effort spent on innovation and the level of innovation success. The other dimensions of organizational learning capability have moderate positive correlations with the dimensions of product innovation performance. Higher levels of organizational learning capability are associated with higher levels of product innovation performance. Failure detection and correction, scanning, and operation and implementation routines are the leading dimensions that improve product innovation performance. 
Table 4: Results of the Multiple Regression Analysis between Dimensions of Organizational Learning Capability and Innovation Efficiency

\begin{tabular}{|c|c|c|c|c|}
\hline Independent Variables & $\begin{array}{l}\text { Standar } \\
\text { d Error }\end{array}$ & Beta & $\begin{array}{l}\mathbf{t} \\
\text { values }\end{array}$ & $\begin{array}{l}\text { Signif } \\
\text { cance } \\
\text { Level }\end{array}$ \\
\hline $\begin{array}{l}\text { Failure Detection and } \\
\text { Correction }\end{array}$ & 0.098 & 0.517 & 4.765 & 0.000 \\
\hline $\begin{array}{l}\text { Operation and } \\
\text { Implementation Routines }\end{array}$ & 0.084 & 0.213 & 2.580 & 0.011 \\
\hline Scanning & 0.115 & 0.385 & 3.931 & 0.000 \\
\hline Continuous Renewal & 0.080 & 0.053 & 0.634 & 0.527 \\
\hline Variety of Ideas & 0.093 & -0.048 & -0.555 & 0.580 \\
\hline Problem Solving & 0.095 & 0.026 & 0.304 & 0.762 \\
\hline
\end{tabular}

Table 4 reports the results of the multiple regression analysis between the dimensions of organizational learning capability and product innovation efficiency; that is to say, the amount of effort spent on developing new products. The table shows that three of the independent variables are significant predictors of the dependent variable: failure detection and correction, operation and implementation routines, and scanning. These variables have high levels of statistical significance $(p=0.00$ and $p<0.005)$. The $R$ value $(0.688)$ represents the correlation between the dependent variable and independent variables. Higher $\mathrm{R}$ values indicate that there is a highly significant relationship between dependent and independent variables. The $\mathrm{R}^{2}$ shows the percentage of variation in the dependent variable that is explained by independent variables. Dimensions of organizational learning capability explain $48 \%$ of the variation in this dimension of product innovation performance. Timely detection and correction of the failures in the processes of an organization, and effective analysis of the internal and external environment have positive effects on the effort spent on developing new products. These findings provide partial support to hypothesis 1 .

Table 5: Results of the Multiple Regression Analysis between Dimensions of Organizational Learning Capability and Innovation Efficacy

\begin{tabular}{lllll}
\hline & $\begin{array}{l}\text { Standard } \\
\text { Error }\end{array}$ & $\begin{array}{l}\text { Beta } \\
\text { Independent Variables }\end{array}$ & $\begin{array}{l}\text { tignific } \\
\text { values } \\
\text { Scanning }\end{array}$ & $\begin{array}{l}\text { ance } \\
\text { Level }\end{array}$ \\
Variety of Ideas & 0.116 & 0.359 & 3.894 & 0.000 \\
Problem Solving & 0.094 & 0.209 & 2.436 & 0.016 \\
$\begin{array}{l}\text { Continuous Renewal } \\
\text { Failure Detection and }\end{array}$ & 0.083 & 0.33 & 0.386 & 0.363 \\
$\begin{array}{l}\text { Correction } \\
\text { Operation and }\end{array}$ & 0.088 & 0.569 & 5.717 & 0.000 \\
Implementation Routines & 0.072 & 0.249 & 2.754 & 0.001 \\
\hline $\mathrm{R}=0.770 \quad \mathrm{R}^{2}=0.593$ & $\mathrm{~F}=27.420 \mathrm{p}=0.000$ & & \\
\hline
\end{tabular}

Table 5 reports the results of the multiple regression analysis conducted to examine the relationship between dimensions of organizational learning capability and innovation efficacy; that is to say, the level of innovation success, in more detail. The table shows that five of the independent variables are significant predictors of the dependent variable: Failure detection and correction, scanning, problem solving, variety of ideas, and operation and implementation routines. These variables have high levels of statistical significance $(\mathrm{p}=0.00$ and $\mathrm{p}<0.005)$. Dimensions of organizational learning capability explain $60 \%$ of the variation in this dimension of product innovation performance. In other words, the model has a high predictive power. The ability of an organization to solve problems quickly and efficiently, to adapt to changes in its internal and external environments and detect opportunities, to facilitate the sharing of different ideas, to analyze the failures in business processes and prepare action plans to address 
these failures, to make successful use of past experiences and accumulated knowledge, and to make these part of its operating routines positively effects the level of innovation success. These findings provide partial support to hypothesis 2 .

\section{Discussion and Conclusions}

This study focused on an interesting topic in the literature: The relationship between organizational learning capability, and a performance indicator affected by this capability, namely, product innovation performance. The findings of the study have implications both for the specific literature and for practitioners. Overall, it was found that most firms who participated in the study possessed organizational learning capability. The average scores, out of 5 , for the dimensions of organizational learning capability were above 4.00 . The lowest scores were received for the dimensions of problem solving and variety of ideas. The relatively lower scores received for problem solving and variety of ideas may be explained with reference to cultural factors, or to the inability on the part of the firms to establish flexible organizational structures. A flexible organizational structure facilitates knowledge sharing through informal communication and control mechanisms, and requires individuals to adapt to changing circumstances and positions rather than adhering to rigid job descriptions. Failure to extend a flexible organizational structure to all the processes in an organization may have stunted the development of variety of ideas, which requires free circulation of knowledge, and problem solving capability, which requires associating activities with one another. In addition, the dominance of collectivism as opposed to individualism in Turkey, and high levels of power distance may have presented obstacles to the free expression of ideas by individuals.

In terms of product innovation performance, firms that participated in the study perceived themselves as having higher levels of innovation efficacy, also known as the level of innovation success, and higher levels of innovation efficiency, also known as the effort put into successful innovation, compared to their rivals. Almost all of the firms that participated in the study had a formal $R \& D$ department. More than half of the participating firms either cooperated with a technology development institute in the past, or have ongoing cooperation on various projects. The firms that participated in the survey have registered a significant number of utility model patents within the last five years. All of these factors are thought to have contributed to the product innovation performance of the firms.

The multiple regression analysis conducted showed that dimensions of organizational learning capability have a positive effect on product innovation performance. Failure detection and correction, scanning, variety of ideas, problem solving, and operation and implementation routines (organizational memory) were found to affect the efficacy dimension of innovation. A firm's ability to detect failures in existing processes and prevent the repetition of these failures in the future by preparing action plans is relatively important for the success of innovation activities. A firm's ability to solve new problems that are not covered by the action plans; to perceive threats and opportunities in a timely manner and take proactive action; to create knowledge, experience, and lessons learned a part of the organizational memory; and to have a structure and a culture that allow the 
expression of new ideas have a positive effect on the level of success of a newly developed product. Dimensions of organizational learning capacity that were found to affect the second dimension of product innovation performance, innovation efficiency were scanning, operation and implementation routines, and failure detection and correction. The ability of the firms to effectively detect failures in their processes and develop action plans to address them, to conduct detailed analyses of their internal and external environments, and to take proactive action to make good use of opportunities were factors that positively affected the effort to develop new products. Similarly, the ability to make knowledge part of the organizational memory and to make effective use of memory increased the effort put into innovation and its efficiency. Findings of the present study on the relationship between organizational learning capability and product innovation performance are in line with those of earlier studies in the literature (Jerez, 2005; Alegre and Chiva, 2008; Sinkula et al. 1997; Calantone et al. 2002).

After this brief recap of the main findings, the contributions of the study to the relevant literature and to business practitioners can be stated as follows: Organizational learning has been the subject of many discussions both in the academic literature and in the business world, but the concept of organizational learning capability has received relatively scant attention to this day. In previous studies, organizational learning is usually measured using dimensions of a learning organization. The scale used in the present study emphasizes, unlike other scales commonly used in the literature, March's (1991) perspective on organizational learning capabilities (exploitative and exploratory capabilities). Thus, the focus in the present study on the dimensions of organizational learning capability, and the use of a scale to examine organizational learning capabilities constitutes an important contribution to the wider literature on organizational learning. This study provides an empirical measurement of organizational learning capability, and examines its relationship with product innovation, which has been the focus of many studies in recent years. There are very few studies in the literature that examine organizational learning capability in the context of product innovation, and the few studies that exist usually adopt a micro perspective and focus on developed economies, with virtually no studies conducted on developing countries (Calantone et al. 2002; Cohen and Levinthal, 1990; Hsu and Fang, 2008). The sample of firms examined in this study is representative of manufacturing companies in a developing economy, adding to the significance of the study. For businesses operating in developing economies, possessing organizational learning capability is considered to be a must to be able to respond to changes in the environment in a timely and effective manner (Çömlek et al. 2012; Dekoulou and Trivallas, 2015; Vargas, 2015), indicating that further studies on this topic, to be conducted in developing economies, would be highly valuable. A notable finding of the study was that continuous renewal, one of the dimensions of organizational learning capability, did not have a significant effect on product innovation performance. This may be attributed to certain deficiencies in the organizational structure and mode of operation of the companies. As Koç and Ceylan (2007) argue, Turkish 
companies lag behind their competitors in terms of teamwork, employee initiative, and organizational learning. These deficiencies may be presenting obstacles to achieving continuous renewal. The failure to detect a significant positive relationship between dimensions of product innovation performance and continuous renewal may also be attributed to the characteristics of the sample. Sectors represented in the sample vary in terms of their innovation levels and other characteristics, which may be responsible for the finding in question.

From the perspective of the business world, the present study calls attention to the importance of developing organizational learning capability and its role in improving performance, and can serve as a guide for companies willing to develop their organizational learning capability, by helping them identify areas in need of improvement. In other words, the findings of this study can help companies develop their organizational learning capability, and achieve sustainable competitiveness through innovation.

\section{Limitations of the Study}

A standard questionnaire form was used to collect the data in this study, and attitude scales were used to measure firms' organizational learning capability and product innovation performance. Executives' responses to the items in the questionnaire may have been affected by their current statuses, value judgments, beliefs, or expectations. In addition, this study examined the relationship between variables using a sample that consisted of large companies, and the relationship may not be the same in the case of SMEs (small and medium enterprises).

\section{Future Research}

Future studies may examine the relationship between organizational learning capability and innovation by including various mediating and moderating variables in the model, such as culture, structures, and social networks. To examine whether the relationship between organizational learning capability and product innovation varies by firm size, similar studies can be conducted with the participation of small and medium sized enterprises.

\section{REFERENCES}

Akgün, A.E., Keskin, H., Byrne, J.C. \& Aren, S. (2007). Emotional and Learning Capability and Their Impact on Product Innovativeness and Firm Performance. Technovation, 27, 501-513.

Alegre, J. \& Chiva, R. (2008). Assessing The Impact of Organizational Learning Capability on Product Innovation Perofrmance: An Emprical Test. Technovation, 28, 315-326.

Argyris, C. \& Schön D. A.. (1996). Organizational Learning II; Theory, Method and Practice. U.S.A.: AddisonWesley Publishing Company.

Atik, H. (2005). Yenilik ve Ulusal Rekabet Gücü. Ankara: Detay Yayıncılık.

Aydemir, M. (2000). Örgütsel Öğrenme ve Toplam Kalite Yönetimi. Dokuz Eylül Üniversitesi, Sosyal Bilimler Enstitüsü Dergisi, 2 (3), 1-9

Barr, P. S., Stimpert, J.L. \& Huff, A.S. (1992). Cognitive Change, Strategic Action and Organizational Renewal. Strategic Management Journal, 13, 15-36.

Batmaz, N. ve Özcan, A. (2008). Yeniliği Etkileyen Unsurlar ve Toplumsal Refah İlişkisi. International Journal of Economic and Administrative Studies, 1 (1), 43-66.

Calantone, R.J. Çavuşgil, T. S., \& Zhao, Y. (2002). Learning Orientation, Firm 
Innovation Capability, And Firm Performance. Industrial Marketing Management, 31, 515-524.

Cohen, W. M. \& Levinthal, D.A. (1990). Absorptive Capacity: A New Perspective on Learning and Innovation. Administrative Science Quarterly, 35 (1), 128-152.

Çömlek, O., Kitapçı, H., Çelik V. ve Özşahin M. (2012). The Effects of Organizational Learning Capacity on Firm Innovative Performance. Procedia - Social and Behavioral Sciences, 41, 367-374.

Daft, R.L. \& Weick, K. E. (1984). Toward a Model of Organizations as Interpretations Systems. Academy of Management Review, 9 (2), 284-295.

Damanpour, F. (1991). Organizational Innovation: A Meta-Analysis of Effects of Determinants and Moderators. Academy of Management Journal, 34 (3), 555-590.

Dekoulou, P ve Trivellas, P. (2015). Measuring the Impact of Learning Organization on Job Satisfaction and Individual Performance in Greek Advertising Sector. Procedia - Social and Behavioral Sciences, 175, 367-375.

Durna, U. (2002). Yenilik Yönetimi. Ankara: Nobel Yayınları.

Fiol, C.M. \& Lyles, A.M. (1985). Organizational Learning. The Academy of Management Review, 10 (4), 803813.

Garbi, E. (1998). Contingencies of Learning: Essays on the Strategic Implacations of Organizational Learning, Organizational Environments and Knowledge Sharing. (Unpublished doctoral dissertation). University of California, Los Angeles.

Garcia, R. \& Calantone R. (2002). A Critical Look at Technological Innovation Typology and Innovativeness Terminology: A Litertaure Review. The Journal of Product Innovation Management, 19 (2), 110-132.
García-Morales, Víctor J., Ruiz-Moreno, Antonia and Llorens-Montes, Francisco J. (2007). Effects of Technology Absorptive Capacity and Technology Proactivity on Organizational Learning, Innovation and Performance: An Empirical Examination, Technology Analysis \& Strategic Management, 19 (4), $527-558$.

Goes, J. B. \& Park, S.H. (1997). Interorganizational Links and Innovation: The Case of Hospital Services. Academy of Management Journal, 40 (3), 673-96.

Goh, S. (2003). Improving Organizational Learning Capability: Lessons from two case studies. The Learning Organization, 10 (4), 216-27.

Gomez, P. J., Lorente, J. C. \& Cabrera, R. V. (2005). Organizational Learning Capability: A proposal of measurement. Journal of Business Research, 58, 715-725.

Güleș, H.K. ve Bülbül, H. (2004). Toplam Kalite Yönetiminin İşletmelerde Yenilik Çalışmalarına Katkıları. G.Ü. İ.İ.B.F. Dergisi, 1, 115-129.

Hambrick, D. C. (1982). Environmental Scanning and Organizational Strategy. Strategic Management Journal, 3 (2), 159-174.

Hsu, Y.H. \& Fang, W. (2008). Intellectual Capital and New Product Development Performance: The Mediating Role of Organizational Learning Capability. Technological Forecasting and Social Change, http://dx.doi.org/10.1016/j.techfore.200 8.03.012, 1-14.

Huber, G.P. (1991). Organizational Learning: The Contributing Process and the Literature. Organization Science, 2 (1), 88-115.

Hult, G.T.M., Hurley, R.F. \& Knight, G.A. (2004). Innovativeness: Its Antecedents and Impact on Business Performance. Industrial Marketing Management, 33, 429-438.

Kirchhoff, A.B. (1994). Entrepreneurship Economics. W.D. Bygrave (Eds.) The Portable MBA in Entrepreneurship (410-436). New York:Wiley\&Sons Inc. 
Koç, T ve Ceylan, C. (2007). Factors impacting the innovative capacity in large-scale companies. Technovation, 27, 105-114.

Koffman, F. \& Senge, P.(1993). The Heart of Learning Organizations. Organizational Dynamics, Autumn, 4-23.

Lynn, G.S., Skov, R.B.\& Abel, K.D. (1999). Practices That Support Team Learning and Their Impact on Speed to Market and New Product Success. Journal of Product Innovation Management, 16: 439-454.

Lynn, G.S., Reilly, R.R. \& Akgün, A.E. (2000). Knowledge Management in New Product Teams: Practices and Outcomes. IEEE Transactions on Engineering Management, 47 (2), 221231.

March, J.G. (1991). Exploration and Exploitation in Organizational Learning. Organization Science, 2 (1), $71-87$.

McGill, M.E. \& Slocum, J.W. (1993). Unlearning the Organization. Organizational Dynamics, Autumn, $67-79$.

Nederhof, P.C.W., Bacitti, B.J., Gomes, J. \& Pearson A. (2002). Tools for The Improvement of Organizational Process in Innovation. Journal of Workplace Learning, 14 (7/8), 320331.

Nonaka, S. \& Takeuchi, N. (1995). The Knowledge Creating Company. New York: Oxford University Press.

Oskarsson, G. (2003). The Ancedents and Process of Innovation. The IV Conference in Social Sciences, University of Iceland, February 21-22, $1-14$.

Özen, Ü. ve Bingöl, M. (2007). İşletmelerde Bilişim Teknolojileri ve Yenilikçilik: Erzurum, Erzincan ve Bayburt'taki KOBİ'lerde Bir Araştırma. Atatürk Üniversitesi Sosyal Bilimler Enstitüsü Dergisi, 10 (2), 399-417.

Pınar, İ. ve Arıkan, C. (2015). Örgütsel Öğrenme Yeteneği ile Örgütsel Yenilik
Arasındaki

İlişki:

Tekstil Sektöründe Bir Araştırma. Istanbul University Journal of the School of Business, 44 (2), 65-76.

Prahalad, C. K. \& Hamel, G. (1994). Strategy as a Field of Study: Why Search For a New Paradigm?. Strategic Management Journal, 15, 5-16.

Prieto, I.M. \& Revilla, E. (2006). Assessing the Impact of Learning Capability on Business Performance: Empirical Evidence from Spain. Management Learning, 37 (4), 499-522.

Phromket, C. \& Ussahawanitchakit, P. (2009). Effects of Organizational Learning Effectiveness on Innovation Outcomes and Export Performance of Garments Business in Thailand. International Journal of Business Research, 9 (7), 6 31.

Santos- Vijande, M.L. \& Alvarez-Gonzalez, L.I. (2007). Innovativeness and Organizational Innovation in Total Quality Oriented Firms: The Moderating Role of Market Turbulence. Technovation, 27, 514532.

Senge, P. M. (2007). Beşinci Disiplin; Öğrenen Organizasyon Düşünüşü ve Uygulamas1. İstanbul: Yap1 Kredi Yayınları.

Simon, H. A. (2000). Observations on the Sciences of Science Learning. Journal of Applied Developmental Pshycology, 21(1), 115-121.

Singh, K. (2006). Assessing Organizational Learning in Indian Business Organizations: An Integrated Approach to Learning Organizations. Second Interantional Conference on Business, Management and Economics, 15-18 June, İzmir, 3, 33-48.

Sinkula, J.M., Baker W.E. \& Noordewier T.A. (1997). Framework for Market-Based Organizational Learning: Linking Values, Knowledge, and Behavior. Journal of Academy Marketing Science, 25 (4), 305- 18.

Spicer, D.P. \& Smith, E.S. (2006). Organizational Learning in Small Manufacturing Firms. International Small Business Journal, 24 (2), 133158. 
Ussahawanitchakit, P. (2008). Organizational Learning Capability, Organizational Commitment, and Organizational Effectiveness: An Empirical Study of Thai Accounting Firms. International Journal of Business Strategy, 8 (3), 112.

Yeung, A.K., Ulrich, D.O., Nason, S.W. \& Glinow, M.A. V. (1999). Organizational Learning Capability. New York: Oxford University Press.

Walsh, J. P. \& Ungson, G.R. (1991). Organizational Memory. The Academy of Management Review, 16 (1), 57-91.

Weick, K. E. (1991). The Nontraditional Quality of Organizational Learning. Organization Science, 2 (1), 116-124.

Van de Ven, A.H. \& Polley, D. (1992). Learning While Innovating. Organization Science, 3 (1), 92-116.

Vargas, M.I.R. (2015). Determinant Factors for Small Business to Achieve Innovation, High Performance and Competitiveness: Organizational Learning and Leadership Style. Procedia - Social and Behavioral Sciences, 169, 43- 52. 